\title{
In Vitro Method To Assess Soil Arsenic Metabolism by Human Gut Microbiota: Arsenic Speciation and Distribution
}

\author{
Naiyi Yin, ${ }^{\dagger}$ Zhennan Zhang, ${ }^{\dagger}$ Xiaolin Cai, ${ }^{\dagger}$ Huili Du, ${ }^{\dagger}$ Guoxin Sun, ${ }^{\ddagger}$ and Yanshan Cui ${ }^{*}{ }^{\dagger}$ \\ ${ }^{\dagger}$ College of Resources and Environment, University of Chinese Academy of Sciences, Beijing 100049, People’s Republic of China \\ ${ }^{\ddagger}$ State Key Laboratory of Urban and Regional Ecology, Research Center for Eco-Environment Sciences, Chinese Academy of \\ Sciences, Beijing 100085, People's Republic of China
}

\section{Supporting Information}

ABSTRACT: Arsenic (As) speciation and distribution are two important factors in assessing human health risk from As-contaminated soil. In this study, we used the combination of physiologically based extraction test (PBET) and Simulator of Human Intestinal Microbial Ecosystem (SHIME) to determine soil As metabolism by human gut microbiota. The results showed that the percentage of soil arsenate $[\mathrm{As}(\mathrm{V})]$ transformation reached 22.1-38.2\%, while that of arsenite [As(III)] attained $66.5-92.0 \% ; 30.1-56.4 \%$ of $\mathrm{As}(\mathrm{V})$ transformed was attached to the soil solid phase. In comparison to sequential extraction results, almost all amorphous $\mathrm{Fe} / \mathrm{Al}$-oxide-bound As was liberated in the colon phase. An X-ray absorption nearedge structure (XANES) showed that the As(III) percentage in the soil solid phase reached $16.6-26.9 \%$ and reached $73.4 \%$ (soil 1) in the colon phase. Additionally, plenty of As(III) and different extents of methylation were also observed in colon extraction solution. As bioaccessibility in the colon phase was 1.8-2.8 times that in the small intestinal phase. Our results indicated that human gut microbiota increased As bioaccessibility, and large amounts of As(III) were adsorbed onto the soil solid phase as a result of microbial reduction. Determining As speciation and distribution in extraction solution and soil solid phases will allow for an accurate assessment of the risk to human health upon soil As exposure.

\section{INTRODUCTION}

Arsenic (As) is a common toxic contaminant that is extensively distributed in the environment. ${ }^{1}$ Human exposure to As in soils is a major public concern and is associated with serious risks to human health because As species are known carcinogens. ${ }^{2,3}$ In most cases, human exposure to soil As occurs via inhalation, inadvertent oral ingestion, and dermal contact. ${ }^{4,5}$ Inadvertent oral ingestion has been considered an important exposure route for soil As, especially ingestion through outdoor hand-to-mouth activities by children..$^{6}$ The estimation of As bioaccessibility (gastric and small intestinal phases) in contaminated soils through in vitro methods has been used for human health risk assessment. On the basis of previous studies, ${ }^{7-9}$ simple, fast, and inexpensive in vitro methods can effectively estimate in vivo relative As bioavailability. Generally, bioaccessibility is defined as the fraction of As that is soluble in the gastrointestinal environment of humans and available for absorption, whereas bioavailability is determined by the fraction of As that is absorbed into the systemic circulation. ${ }^{7,8}$ Currently, As bioaccessibility in the gastric and small intestinal phases may underestimate its harm to human health. ${ }^{10}$ Studies have clearly illustrated that gut microbiota significantly affect As metabolism by, for example, reduction, methylation, and thiolation. ${ }^{11}$ As metabolism in contaminated soil by human gut microbiota can affect As bioaccessibility and speciation..$^{10,12}$ Therefore, As biotransformation must be considered an essential part of the risk assessment of oral soil As exposure using in vitro methods.

The structure and activity of human gut microbiota varies greatly with diet, gender, age, and region; ${ }^{13-15}$ accordingly, it was essential and urgent to investigate differences in As metabolism by gut microbiota in various populations. The Simulator of Human Intestinal Microbial Ecosystem (SHIME) describes the colon microbial community of human origin ${ }^{16}$ based on other in vitro methods. This model has showed that human gut microbiota actively metabolize As and increase As bioaccessibility in food and contaminated soils. ${ }^{12,17}$ Human gut microbiota not only change the speciation of soil As but also induce changes from inorganic As (iAs) to organic As. As species have been detected in colon extraction solutions, ${ }^{10}$ including iAs, low-toxicity monomethylarsonic acid $\left(\mathrm{MMA}^{\mathrm{V}}\right)$ and dimethylarsinic acid $\left(\mathrm{DMA}^{\mathrm{V}}\right)$, highly toxic monomethylarsonous acid $\left(\mathrm{MMA}^{\mathrm{III}}\right)$, and monomethylmonothioarsonic acid $\left(\mathrm{MMMTA}^{\mathrm{V}}\right)$ with unknown toxicity. The metabolism of As by gut microbiota has primarily been investigated on the basis of animal tests; $\mathrm{As}(\mathrm{V})$ can be reduced to As(III) by rat cecal bacteria. ${ }^{18}$ Furthermore, methylated metabolites can be

Received: June 24, 2015

Revised: $\quad$ August 4, 2015

Accepted: August 6, 2015

Published: August 6, 2015 
Table 1. Physicochemical Properties of the Soils $(n=3)$

\begin{tabular}{|c|c|c|c|c|c|c|c|c|c|c|c|c|}
\hline sample & site & type & $\begin{array}{l}\mathrm{OM} \\
(\%)\end{array}$ & $\mathrm{pH}$ & $\begin{array}{l}\text { clay } \\
(\%)\end{array}$ & $\begin{array}{c}\mathrm{Fe} \\
\left(\mathrm{g} \mathrm{kg}^{-1}\right)\end{array}$ & $\begin{array}{c}\mathrm{Mn} \\
\left(\mathrm{g} \mathrm{kg}^{-1}\right)\end{array}$ & $\left(\begin{array}{c}\mathrm{Al} \\
\left(\mathrm{g} \mathrm{kg}^{-1}\right)\end{array}\right.$ & $\begin{array}{c}\mathrm{Fe}^{a} \\
\left(\mathrm{~g} \mathrm{~kg}^{-1}\right)\end{array}$ & $\begin{array}{c}\mathrm{Mn}^{a} \\
\left(\mathrm{mg} \mathrm{kg}^{-1}\right)\end{array}$ & $\begin{array}{c}\mathrm{Al}^{a} \\
\left(\mathrm{~g} \mathrm{~kg}^{-1}\right)\end{array}$ & $\begin{array}{c}\text { As } \\
\left(\mathrm{mg} \mathrm{kg}^{-1}\right)\end{array}$ \\
\hline soil 1 & $\begin{array}{l}\text { Chifeng, Inner } \\
\text { Monglia }\end{array}$ & mining & 1.7 & 7.4 & 0.8 & 21.1 & 1.5 & 23.8 & 1.9 & 539.9 & 0.9 & 110.9 \\
\hline soil 2 & Dalian, Liaoning & mining & 1.5 & 3.5 & 0.3 & 191.1 & 0.1 & 10.8 & 28.2 & 30.2 & 3.6 & 802.5 \\
\hline soil 3 & Shangyu, Zhejiang & farmland & 2.3 & 7.4 & 1.7 & 35.6 & 0.8 & 48.4 & 5.2 & 324.6 & 0.6 & 323.9 \\
\hline soil 4 & Shimen, Hunan & farmland & 4.0 & 7.3 & 20.9 & 25.9 & 0.5 & 38.7 & 3.2 & 110.0 & 0.8 & 419.9 \\
\hline soil 5 & Chenzhou, Hunan & farmland & 3.6 & 7.6 & 43.5 & 27.5 & 0.5 & 53.8 & 2.6 & 370.0 & 1.3 & 143.3 \\
\hline
\end{tabular}

detected in the urinary excretions of rats that were orally exposed to different As compounds, ${ }^{19,20}$ and microbial thiolation has been reported during in vivo experiments. ${ }^{21}$ In soil, As mobility is mainly controlled by adsorption/desorption processes and co-precipitation with metal oxides. As mobility is greatly enhanced by the reductive dissolution of $\mathrm{Fe}$ (III) oxides and $\mathrm{As}(\mathrm{V})$ reduction under anaerobic environments. ${ }^{2-24}$ However, there is no information regarding As speciation and As mineralogy in the soil solid phase of the colon phase using the existing in vitro methods. Only Smith et al. have investigated the As speciation of residual soils in the gastric and small intestinal phases by X-ray absorption near-edge structure (XANES). ${ }^{25}$

Identifying As speciation and distribution (the concentration of different As speciations in the extraction solution and soil solid phase of colon incubation, respectively) would result in more accurate risk assessment associated with potential human exposure to contaminated soil. In the colon phase, the amount and percentage of soil As metabolism by human gut microbiota, along with the distribution of different As species in the colon extraction solution and soil solid phase, are not well-known. In the previous studies, the combination of the in vitro gastrointestinal extraction method (IVG) and SHIME model was chosen in As-contaminated soil, ${ }^{10}$ and the Unified Bioaccessibility Research Group of Europe (BARGE) method (UBM) combined with SHIME was used for assessing As risk in rice. ${ }^{17}$ The physiologically based extraction test (PBET) is a classic and mature in vitro method to assess As bioaccessibility in the gastric and small intestinal phases. ${ }^{9,26}$ Therefore, in this study, the PBET method combined with the SHIME model was used to investigate (1) As metabolism of contaminated soils by human gut microbiota, (2) As bioaccessibility and its speciation in the small intestinal and colon phases, and (3) As distribution between extraction solution and the soil solid phase.

\section{MATERIALS AND METHODS}

As-Contaminated Soil. Five surface $(0-20 \mathrm{~cm}$ depth) soil samples were collected from a range of mining and farmland locations in China. The soil samples covered a range of soil physicochemical properties and high concentrations of total As (Table 1). All soil samples were air-dried and sieved to a particle size fraction of $<250 \mu \mathrm{m}$ for in vitro studies; this particle size is most likely to stick to the hands of exposed humans. ${ }^{27}$ Soil physicochemical properties were measured on duplicate samples. Soil $\mathrm{pH}$ was determined in a $1: 2.5(\mathrm{w} / \mathrm{v})$ soil/ deionized water suspension of the soil after $0.5 \mathrm{~h}$ of equilibration. The concentration of soil organic matter (OM) was determined by the acid dichromate oxidation method ${ }^{28}$ and analyzed by ultraviolet/visible (UV/vis) spectrophotometry. Soil particle size (soil $\mathrm{OM}$ dislodged by $\mathrm{H}_{2} \mathrm{O}_{2}$ ) was analyzed using a laser particle size analyzer (Mastersizer 2000, Malvern, U.K.). ${ }^{29}$ The oxalate-extractable iron, aluminum, and manganese concentrations of the soils were determined using acid ammonium oxalate extraction. ${ }^{30}$ The concentrations of total As and other metals were determined by inductively coupled plasma-optical emission spectroscopy (ICP-OES, PerkinElmer, Waltham, MA) or inductively coupled plasma-mass spectrometry (ICP-MS, Agilent 7500a, Santa Clara, CA) by acid digestion with aqua regia $\left(\mathrm{HNO}_{3} / \mathrm{HCl}=1: 3\right.$ in volume $)$ and $\mathrm{HClO}_{4}$ (1:1 in volume). In the digestion process, the blank (no soil added) and standard soil samples (GSS-5, National Institute of Metrology, China) ensured the accuracy and recovery rate (95-110\%), which ensures that internal quality assurance/quality control (QA/QC) practices are satisfied.

Sequential Soil As Fractionation. A sequential As fractionation scheme based on the modified method ${ }^{31}$ was employed to determine the following operationally defined As forms: (F1) non-specifically adsorbed, (F2) specifically adsorbed, (F3) amorphous $\mathrm{Fe}$ and $\mathrm{Al}$ oxides, (F4) crystalline $\mathrm{Fe}$ and $\mathrm{Al}$ oxides, and (F5) residual phase. Centrifuged supernatants were filtered $(0.45 \mu \mathrm{m})$ and analyzed for total soluble As using ICP-MS.

Dynamic SHIME. The in vitro colon microbial community used in the experiments was cultured and maintained in a modified SHIME as previously described. ${ }^{32}$ The SHIME consisted of five compartments simulating the stomach, small intestine, ascending colon, transverse colon, and descending colon. In previous studies about SHIME, fresh fecal microorganisms were obtained from one volunteer with no history of antibiotic treatment in the 6 months before the study, ${ }^{10,12,17}$ and we chose one Chinese volunteer. Briefly, fresh fecal microorganisms obtained from a Chinese 28-year-old male volunteer were inoculated in three colon compartments. Feed solution was added 3 times per day to provide digested nutrition for the colon microorganisms. The temperature (37 $\left.{ }^{\circ} \mathrm{C}\right)$ and $\mathrm{pH}$ (5.6-5.9, 6.15-6.4, and 6.7-6.9 in the ascending colon, transverse colon, and descending colon, respectively) were controlled automatically. The SHIME reactors were continuously stirred and kept under anaerobic by regularly flushing with nitrogen. After 3-4 weeks of adaptation, stable microbial communities were obtained in the colon compartments. The colon compartments of SHIME are detailed in the Supporting Information.

Estimation of Bioaccessibile As. The bioaccessibility of soil As from five soils was investigated using the PBET method (small intestinal phase) combined with the SHIME model (colon phase). The PBET method was modified ${ }^{8,33}$ from the procedure described by Ruby et al. ${ }^{9}$ In brief, soils ( $\left.0.3 \mathrm{~g}\right)$ were added to polypropylene conical centrifuge tubes $(50 \mathrm{~mL})$ with the gastric and small intestinal solutions $(30 \mathrm{~mL})$ at a soil/ solution $(\mathrm{s} / \mathrm{s})$ ratio of $1: 100$. Following the small intestinal 

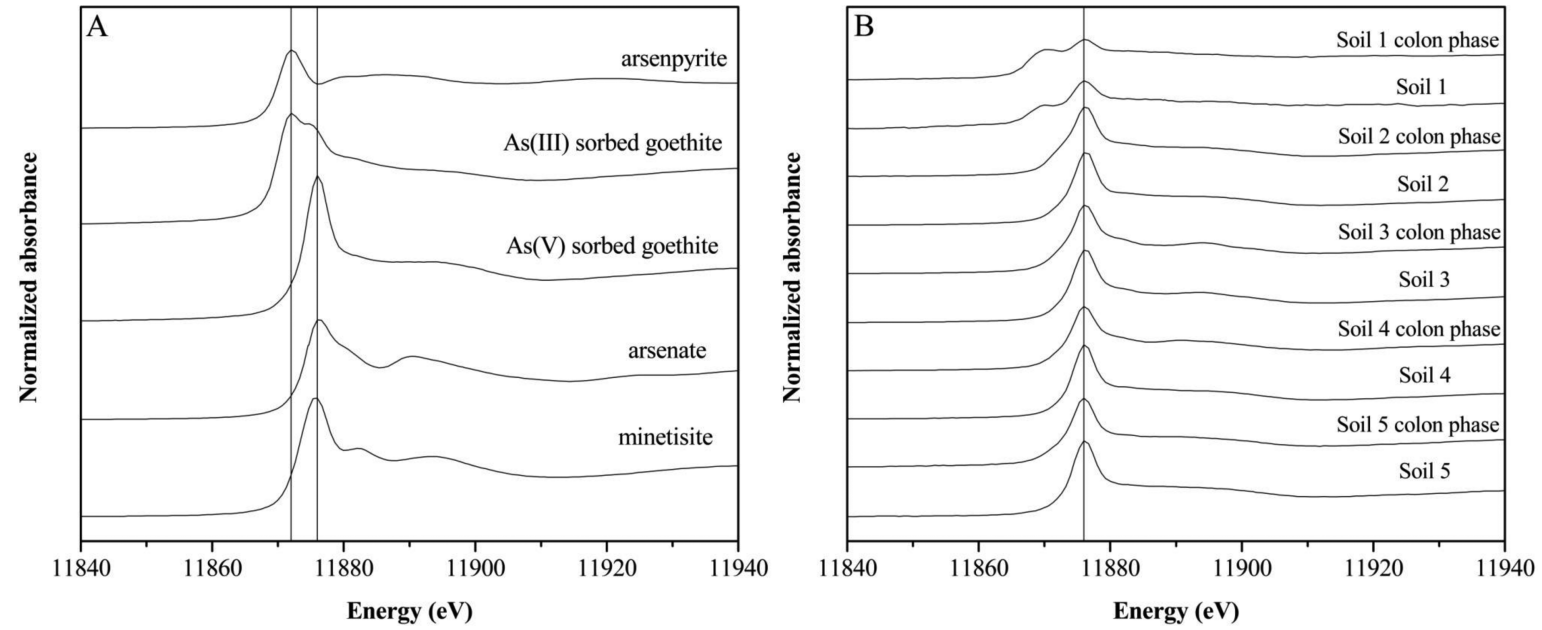

Figure 1. Normalized XANES spectra comparing (A) reference materials and (B) soil samples during in vitro experiments.

phase, these digests were transferred into $100 \mathrm{~mL}$ anaerobic serum bottles with $30 \mathrm{~mL}$ of colon solution from the descending colon compartment of the dynamic SHIME system at a ratio $(\mathrm{s} / \mathrm{s})$ of 1:200. The bottles were capped with butyl rubber stoppers and immediately flushed with nitrogen gas for $20 \mathrm{~min}$ to obtain anaerobic conditions. The digests were shaken at $150 \mathrm{rpm}$ and incubated at $37^{\circ} \mathrm{C}$ for 18 and $48 \mathrm{~h}^{10,12,17}$ The experiments were conducted in triplicate.

Sample Treatment and As Speciation Analysis. All samples taken from the small intestinal and colon phases were centrifuged at $10000 \mathrm{~g}$ for $10 \mathrm{~min}$. The supernatants were filtered $(0.45 \mu \mathrm{m})$ and subsequently stored at $-80{ }^{\circ} \mathrm{C}$ until analysis. As speciation was determined by high-performance liquid chromatography coupled with inductively coupled plasma-mass spectrometry (HPLC-ICP-MS) as described. Chromatographic columns were obtained from Hamilton and consisted of a pre-column $(11.2 \mathrm{~mm}, 12-20 \mu \mathrm{m})$ and a PRP$\mathrm{X} 10010 \mu \mathrm{m}$ anion-exchange column $(250 \times 4.1 \mathrm{~mm})$. The mobile phase consisted of $10 \mathrm{mM}\left(\mathrm{NH}_{4}\right)_{2} \mathrm{HPO}_{4}$ and $10 \mathrm{mM}$ $\mathrm{NH}_{4} \mathrm{NO}_{3}$ adjusted to $\mathrm{pH} 6.2$ using nitric acid. The flow rate was $1 \mathrm{~mL} \mathrm{~min}{ }^{-1}$. As forms in the small intestinal and colon phase extraction solutions were identified by comparing their retention times to those of the standards [As(III), As(V), $\mathrm{DMA}^{\mathrm{V}}, \mathrm{MMA}^{\mathrm{V}}$, and $\mathrm{MMMTA}^{\mathrm{V}}$ ] quantified by external calibration curves with peak areas. MMMTA ${ }^{\mathrm{V}}$ was synthesized using a mixture of $\mathrm{MMA}^{\mathrm{V}}$ and $\mathrm{H}_{2} \mathrm{~S}$ solutions by this method. ${ }^{10,34}$ The sum of As species in the filtrate $(0.45 \mu \mathrm{m})$ observed chromatographically was considered the bioaccessible As. In addition, the chromatographic recovery by this method was validated, ${ }^{5}$ and the recovery of 1 NIST reference material (2710a) was $98.2 \%$.

As K-Edge XANES Analysis. XANES studies were performed on beamline 1W2B at the Beijing Synchrotron Radiation Facility (BSRF), China. The electron beam energy was $2.5 \mathrm{GeV}$, with a maximum beam current of $250 \mathrm{~mA}$. The change in soil As speciation between the original soil and the soil solid phase of the colon phase was investigated by XANES. The As XANES analysis of the solid phase (soil, ferrihydrite, and scorodite) in the gastric and small intestinal phases was observed previously. ${ }^{25,35}$ After the colon phase, residual soil (soil solid phase of the colon phase) was collected. Following three washes with deionized water, samples were freeze-dried and then pressed into a cake or mounted on Kapton tape prior to XANES analysis. As K-edge XANES spectra were collected at room temperature in fluorescence mode for the samples and in transmission mode for the reference materials. Data analysis was conducted using Athena. ${ }^{36}$ Every sample was normalized, and linear combination fitting (LCF) was then used to identify the As species. ${ }^{37}$ Reference materials included arsenate sorbed to goethite [sorbed $\mathrm{As}(\mathrm{V})$ ] and arsenite sorbed to goethite [sorbed $\mathrm{As}(\mathrm{III})],{ }^{38}$ arsenate $\left(\mathrm{Na}_{2} \mathrm{HAsO}_{4} \cdot 7 \mathrm{H}_{2} \mathrm{O}\right)$, scorodite $\left(\mathrm{FeAsO}_{4} \cdot 2 \mathrm{H}_{2} \mathrm{O}\right)$, minetisite $\left[\mathrm{Pb}_{5}\left(\mathrm{AsO}_{4}\right)_{3} \mathrm{Cl}\right]$, arsenopyrite (FeAsS), realgar $\left(\mathrm{As}_{4} \mathrm{~S}_{4}\right)$, and orpiment $\left(\mathrm{As}_{2} \mathrm{~S}_{3}\right)$.

\section{RESULTS AND DISCUSSION}

As Bioaccessibility and Speciation in the Colon Solution. The As bioaccessibilities in the small intestinal and colon phases were highly variable among the five soils (Table $\mathrm{S} 1$ ). The As bioaccessibility in the colon phase was 1.8-2.8 times that in the small intestinal phase. Similar results indicating higher As bioaccessibility in the colon phase have been shown in previous studies in which human gut microbiota increased As bioaccessibility in contaminated soil, ${ }^{12}$ while Van de Wiele et al. found that As bioaccessibility in the colon phase is lower than that in the small intestinal phase. ${ }^{10}$ The experiment (Table S2) with sterile and active colon suspension from the dynamic SHIME provided evidence regarding the metabolic potency of the human fecal microbial inoculums toward As $(\mathrm{V})(90 \mathrm{mg}$ $\left.\mathrm{L}^{-1}\right){ }^{39}$ In the small intestinal extraction solution, the predominant As form was As $(\mathrm{V})>99 \%$, with the exception of $78.8 \%$ in soil 1 . In the colon phase, a large amount of As(III) was generated and the concentration of $\mathrm{As}(\mathrm{V})$ increased slightly. In this study, iAs species were predominant in the small intestinal and colon phases. These variable results may be attributed to differences in the compositions of gastric and small intestinal phases among in vitro methods. Nevertheless, other soil properties may also affect As bioaccessibility. ${ }^{26,40}$ We observed that the concentrations of bioaccessible As increased with a higher total As concentration and less oxalate-extractable $\mathrm{Mn}$ in the soil (Figure S1). Additionally, soil 1, which was dominated by a higher amount of residual phase $(68.4 \%$; Table S4), exhibited a low As bioaccessibility. The duration is an important parameter in the accurate determination of As bioaccessibility and speciation using in vitro methods. ${ }^{31,41}$ In the present study, the long colon residence time did not facilitate As dissolution; similar results have also been reported for scorodite and rice. ${ }^{12,17}$ 
Table 2. As Speciation, Distribution, and Transformation Rate of As(V) in the Colon Extraction Solution and Soil Solid Phase

\begin{tabular}{|c|c|c|c|c|c|c|c|}
\hline \multirow[b]{3}{*}{ sample } & \multicolumn{4}{|c|}{ colon phase } & \multirow{2}{*}{\multicolumn{2}{|c|}{$\frac{\text { soil }}{\text { prior to in vitro method }}$}} & \multirow[b]{3}{*}{ transformation rates of $\operatorname{As}(\mathrm{V})\left(\mu \mathrm{g} \mathrm{h}^{-1} \mathrm{~g}^{-1}\right)$} \\
\hline & \multicolumn{2}{|c|}{ extraction solution } & \multicolumn{2}{|c|}{ soil solid phase } & & & \\
\hline & $\operatorname{As}(\mathrm{III})\left(\mathrm{mg} \mathrm{kg}^{-1}\right)$ & $\operatorname{As}(\mathrm{V})\left(\mathrm{mg} \mathrm{kg}^{-1}\right)$ & As(III) (\%) & $\operatorname{As}(\mathrm{V})(\%)$ & $\operatorname{As}(\mathrm{III})(\%)$ & $\operatorname{As}(\mathrm{V})(\%)$ & \\
\hline soil 1 & 7.1 & 11.8 & 73.4 & 26.6 & 48.7 & 51.7 & 0.5 \\
\hline soil 2 & 68.4 & 208.5 & 26.9 & 73.0 & 3.2 & 96.6 & 4.1 \\
\hline soil 3 & 25.4 & 67.7 & 17.6 & 82.4 & & 100 & 1.5 \\
\hline soil 4 & 64.9 & 123.3 & 16.6 & 83.4 & & 100 & 2.5 \\
\hline soil 5 & 11.4 & 22.0 & 19.7 & 80.3 & & 100 & 0.9 \\
\hline
\end{tabular}

${ }^{a}$ Calculated by the change of $\mathrm{As}(\mathrm{V})$ in the colon extraction solution and soil phase by the initial soil As concentration and the incubation time of 48 h.
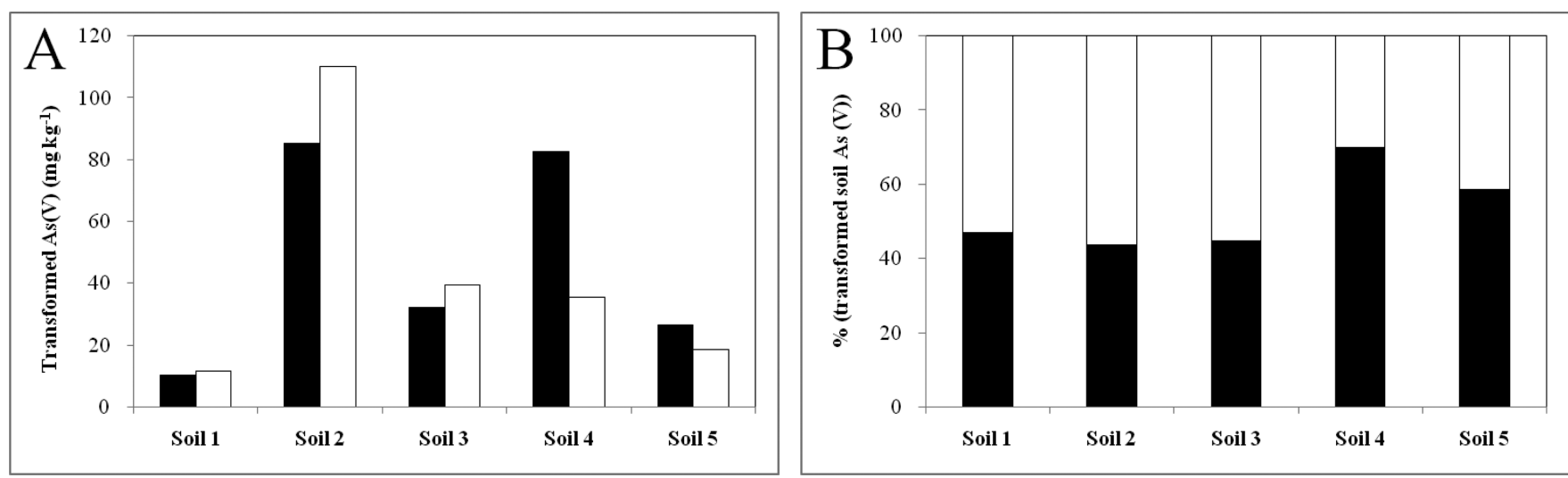

Figure 2. (A) Concentrations and (B) distribution proportion of the transformed soil As(V) in the extraction solution (black) and soil solid phase (white) of the colon phase.

In the colon phase, the formation of $\mathrm{DMA}^{\mathrm{V}}, \mathrm{MMA}^{\mathrm{V}}$, and MMMTA $^{\mathrm{V}}$ was detected. Methylated arsenicals accounted for $6.1-31.1 \%$ of the total As in the colon extraction solution, indicating different extents of methylation. In a previous study, $\mathrm{MMA}^{\mathrm{III}}$ was detected but $\mathrm{DMA}^{\mathrm{V}}$ was not, with different extents of As methylation of $4.7-22.8 \%$ also observed. ${ }^{10}$ These organic As species have been observed by in vivo experiments. ${ }^{19-21}$ Generally, iAs is absorbed in the small intestine, especially by ingesting As in a soluble matrix. ${ }^{42}$ However, a large fraction of soil-bound As can end up in the colon, where an abundant microbial community resides, and methylation and thiolation by human gut microbiota have been found previously in the colon phase. $^{10,34}$ Studies have indicated that $\mathrm{MMA}^{\mathrm{V}}$ can be regarded as an intermediate in the production of $\mathrm{MMMTA}^{\mathrm{V}}$ by microbial thiolation; $\mathrm{MMA}^{\mathrm{V}}$ can even be reduced to highly toxic $\mathrm{MMA}^{\mathrm{III}}$ under the strongly reducing conditions of SHIME. Furthermore, $\mathrm{H}_{2} \mathrm{~S}$ as a sulfide source can induce As thiolation by sulfate-reducing bacteria from the human intestinal tract. ${ }^{34}$ Although As metabolism by human gut microbiota was previously reported, ${ }^{10,17,34}$ this is the first study to report As metabolism by gut microbiota from Chinese people with a high degree of reduction and methylation.

As Speciation in the Soil Solid Phase. The As K-edge XANES results for the soil samples and reference materials are shown in Figure 1, Table 2, and Table S3. To our knowledge, this represents the first XANES investigation of As speciation in the soil solid phase of the colon phase that can provide evidence regarding As distribution. The results indicated that the predominant As form in soil prior to the in vitro experiment was $\mathrm{As}(\mathrm{V})>96 \%$, with the exception of soil 1, followed by arsenopyrite (48.7\%), sorbed As(V) (30.4\%), and minetisite (21.3\%) (Table S3). Interestingly, the percentage of As(III) (of sum As in soil solid phase) reached $73.4 \%$ (soil 1) and 16.6$26.9 \%$ (soils 2-5) (Table 2) in the colon phase, indicating that a certain amount of $\mathrm{As}$ (III) was adsorbed to the soil solid phase, acting as a temporary As repository.

In general, iAs can be the predominant form of As in contaminated soils. Under neutral conditions, the adsorption affinity of organic As to metal minerals is less than that of inorganic As; ${ }^{43}$ thus, it is reasonable to hypothesize that most As exists as $\mathrm{As}(\mathrm{III})$ and $\mathrm{As}(\mathrm{V})$ in the soil solid phase of the colon phase. Summarizing the As speciation change, we calculated the $\mathrm{As}(\mathrm{V})$ transformation rates by human gut microbiota, which means the total concentration of soil As(V) transformed in the extraction solution and soil solid phase of colon incubation every hour, to be $0.5 \mu \mathrm{g} \mathrm{h}^{-1} \mathrm{~g}^{-1}$ (soil 1), 4.1 $\mu \mathrm{g} \mathrm{h}^{-1} \mathrm{~g}^{-1}$ (soil 2), $1.5 \mu \mathrm{g} \mathrm{h}^{-1} \mathrm{~g}^{-1}$ (soil 3), $2.5 \mu \mathrm{g} \mathrm{h}^{-1} \mathrm{~g}^{-1}$ (soil 4), and $0.9 \mu \mathrm{g} \mathrm{h}^{-1} \mathrm{~g}^{-1}$ (soil 5) (Table 2). The As(V) transformation rate was positively related to the amount of oxalate-extractable $\mathrm{Fe}$ and total As in soil and inversely related to the amount of oxalate-extractable Mn. Previous studies have determined the methylation rate from rat and human gut microbiota. ${ }^{10,44}$ However, the transformation rate of $\mathrm{As}(\mathrm{V})$ in the colon extraction solution and the soil solid phase can provide a better understanding of the soil As metabolic capability by human gut microbiota. In addition, the distribution ratios of $\mathrm{As}(\mathrm{III})$ and $\mathrm{As}(\mathrm{V})$ in the colon extraction solution and the soil solid phases were different. The amount of As(III) in the soil solid phase was 9.2 (soil 1), 2.0 (soil 2), 1.6 (soil 3), 0.5 (soil 4), and 1.6 (soil 5) times that in the colon extraction solution, while the amount of $\mathrm{As}(\mathrm{V})$ was 1.4-3.5 times. The results showed that the percentage of soil As(V) transformed by gut microbiota reached $22.1-38.2 \%$ and the amount of As(III) remaining in the soil solid phase reached 
$30.1-56.4 \%$ (Figure 2). The percentage of As(III) as a result of microbial reduction reached $83.3-92.0 \%$ of total transformed soil As(V), with the exception of soil 4 (66.5\%), which exhibited higher methylation. As $(\mathrm{V})$ reduction was affected not only by gut microbiota but also by soil $\mathrm{pH}$ and oxalateextractable $\mathrm{Fe}$ and $\mathrm{Mn}$. A large amount of $\mathrm{As}$ (III) was generated with higher oxalate-extractable $\mathrm{Fe}$ and lower soil $\mathrm{pH}$ and oxalate-extractable $\mathrm{Mn}$ concentrations. Hence, the increase in As(III) should be the result of synergistic processes, including the reductive dissolution of $\mathrm{Fe}$ (III) and the liberation and biotransformation of $\mathrm{As}(\mathrm{III} / \mathrm{V})$; however, there are limited data regarding As speciation in the soil solid phase of the colon phase. Fortunately, some studies have reported As(V) reduction from As-bearing minerals in the presence of Asreducing bacteria; in these cases, As(III) is absorbed by the solid phase in anaerobic environments. ${ }^{24,45}$

Soil As Fractions. The concentrations of different As fractions were highly variable among the five soils (Table S4), which is indicative of the variable physicochemical properties. The non-specifically adsorbed As concentrations were below $1.0 \%$ (of total As). As was mostly bound to the residual phase (68.4\%, step 5) in soil 1 and to crystalline oxides in soil 3 $(45.8 \%$, step 4$)$, whereas in soil 2 , it was primarily associated with amorphous $\mathrm{Fe}$ oxides (36.1\%, step 3$)$. Linear correlation analysis showed that the total soil F1, F2, and F3 fractions and transformed soil As $(\mathrm{V})$ are strongly correlated $\left(r^{2}=0.97 ; n=\right.$ 5) (Figure S2). Whitacre found that soil F1 and F2 fractions contributed more to bioaccessible As than the others in the gastric and small intestinal phases. ${ }^{46}$ Interestingly, in the present study, we can infer that almost all As bound to amorphous $\mathrm{Fe}$ and $\mathrm{Al}$ oxides and a small amount of As associated with crystalline $\mathrm{Fe}$ and $\mathrm{Al}$ oxides was liberated by human gut microbiota. In anaerobic environments, the adsorption capacity of the solid phase for As is weaker because of the reductive dissolution of $\mathrm{Fe}$ (III) oxides in the presence of $\mathrm{Fe}(\mathrm{III})$-reducing bacteria; consequently, As mobility is greatly enhanced. ${ }^{22}$ In addition, As(V) methylation and reduction from As(V)-bearing ferrihydrite, goethite, and other metal oxides can also increase soil As release. ${ }^{23,24}$ Under the anaerobic conditions of the colon phase, there is likely abundant gut microbiota containing similar functional bacteria. ${ }^{10,34}$ As mentioned, $\mathrm{Mn}$ oxides capable of As(III) oxidation and As $(V)$ sequestration ${ }^{47}$ were found to be inversely related to the concentrations of bioaccessible As and As(III) generated in the colon phase. Interestingly, by comparison, As bound to amorphous $\mathrm{Fe}$ and $\mathrm{Al}$ oxides was not liberated only in soil 2, which had a particularly high concentration of transformed soil $\mathrm{As}(\mathrm{V})\left\{403.7 \mathrm{mg} \mathrm{kg}^{-1}\right.$ [calculated by the As(V) concentration in the original soil minus the $\mathrm{As}(\mathrm{V})$ concentration in the soil solid phase after the colon phase]; Figure 2\} and a high transformation rate $\left(4.1 \mu \mathrm{g} \mathrm{h}^{-1} \mathrm{~g}^{-1}\right.$; Table 2$)$. The amount of As $(\mathrm{V})$ reduced to As(III) exceeded $100 \mathrm{mg} \mathrm{kg}^{-1}$ in both soils 2 and 4, which can explain the loss of microbial activity, because there was much more toxic As(III) compared to As(V). It might be that $\mathrm{As}(\mathrm{V})$ transformation by human gut microbiota can reach saturation or limitation in the presence of vast amounts of $\mathrm{As}(\mathrm{V})$, which is worthy of investigation in the further research.

During in vitro experiments, the mobility of As in the soil is mainly controlled by adsorption/desorption processes involving metal oxides. ${ }^{25,35,40}$ Gut microbiota can play a key role in mediating As speciation and can competitively adsorb on the soil solid phase at the same As. ${ }^{10,47}$ The synergistic effect of these processes can control As transformation, liberation, and sequestration in the soil, resulting in dynamic As equilibrium between the colon extraction solution and the soil solid phase. Thus, diets that can induce changes in the gut environment rapidly and reproducibly alter the human gut microbiota. ${ }^{14}$ This can significantly affect As metabolism and mobility. Within the colon phase, $\mathrm{As}(\mathrm{III})$ and $\mathrm{As}(\mathrm{V})$ can be liberated from the soil solid phase as an environmental response, resulting in more uncertain risk.

In summary, soil As(V) transformation by human gut microbiota increased As bioaccessibility and might enhance the potential risk for human health. Our results highlighted that a certain amount of toxic As(III) as a result of microbial reduction was adsorbed to the soil solid phase as a temporary As repository. This will reduce the risk to human health when As(III) adsorbed on soil can favorably excrete with feces without redesorption. Identifying As speciation and distribution in the extraction solution and the soil solid phase of the colon phase will allow for the accurate assessment of the potential risk to human health as a result of soil As exposure.

\section{ASSOCIATED CONTENT}

\section{Supporting Information}

The Supporting Information is available free of charge on the ACS Publications website at DOI: 10.1021/acs.est.5b03046.

Details of the composition for PBET and SHIME, standard control of dynamic SHIME, As bioaccessibility and concentrations of different As species in the small intestinal and colon phases (Table S1), influence of sterile and active colon suspension toward As metabolism (Table S2), linear combination fitting (LCF)XANES analysis of soil samples yielding information on As speciation during the in vitro experiment (Table S3), concentrations of sequential extraction of soil As (Table S4), correlation between the bioaccessible As in the small intestinal and colon phases and the total As and oxalateextractable Mn (Figure S1), and correlation between reduced soil As $(\mathrm{V})$ in the soil solid phase and sequential extraction of soil F1, F2, and F3 As (Figure S2) (PDF)

\section{AUTHOR INFORMATION}

\section{Corresponding Author}

*Telephone: +86-10-8825-6467. Fax: +86-10-8825-6415. Email: cuiyanshan@ucas.ac.cn.

\section{Notes}

The authors declare no competing financial interest.

\section{ACKNOWLEDGMENTS}

The authors acknowledge the support of the National Natural Science Foundation of China (41271493). The authors also thank the Beijing Synchrotron Radiation Facility (BSRF) for the valuable beamtime.

\section{REFERENCES}

(1) Bhattacharya, P.; Welch, A. H.; Stollenwerk, K. G.; McLaughlin, M. J.; Bundschuh, J.; Panaullah, G. Arsenic in the environment: Biology and Chemistry. Sci. Total Environ. 2007, 379 (2-3), 109-120.

(2) Agency for Toxic Substances and Disease Registry (ATSDR). Toxicological Profile for Arsenic; ATSDR: Atlanta, GA, 2007; http:// www.atsdr.cdc.gov/toxprofiles/tp2.pdf. 
(3) Wang, S. L.; Mulligan, C. N. Speciation and surface structure of inorganic arsenic in solid phases: A review. Environ. Int. 2008, 34 (6), $867-879$.

(4) United States Environmental Protection Agency (U.S. EPA). Child-Specific Exposure Factors Handbook; U.S. EPA: Washington, D.C., 2008, http://cfpub.epa.gov/ncea/cfm/recordisplay.cfm?deid= 199243.

(5) Zhu, Y. G.; Sun, G. X.; Lei, M.; Teng, M.; Liu, Y. X.; Chen, N. C.; Wang, L. H.; Carey, A. M.; Deacon, C.; Raab, A.; Meharg, A. A.; Williams, P. N. High percentage inorganic arsenic content of mining impacted and nonimpacted Chinese rice. Environ. Sci. Technol. 2008, 42 (13), 5008-5013.

(6) Ljung, K.; Selinus, O.; Otabbong, E.; Berglund, M. Metal and arsenic distribution in soil particle sizes relevant to soil ingestion by children. Appl. Geochem. 2006, 21 (9), 1613-1624.

(7) Juhasz, A. L.; Weber, J.; Smith, E.; Naidu, R.; Rees, M.; Rofe, A.; Kuchel, T.; Sansom, L. Assessment of four commonly employed in vitro arsenic bioaccessibility assays for predicting in vivo relative arsenic bioavailability in contaminated soils. Environ. Sci. Technol. 2009, 43 (24), 9487-9494.

(8) Rodriguez, R. R.; Basta, N. T.; Casteel, S. W.; Pace, L. W. An in vitro gastrointestinal method to estimate bioavailable arsenic in contaminated soils and solid media. Environ. Sci. Technol. 1999, 33 (4), 642-649.

(9) Ruby, M. V.; Davis, A.; Schoof, R.; Eberle, S.; Sellstone, C. M. Estimation of lead and arsenic bioavailability using a physiologically based extraction test. Environ. Sci. Technol. 1996, 30, 422-430.

(10) Van de Wiele, T.; Gallawa, C. M.; Kubachka, K. M.; Creed, J. T.; Basta, N.; Dayton, E. A.; Whitacre, S.; Du Laing, G.; Bradham, K. Arsenic metabolism by human gut microbiota upon in vitro digestion of contaminated soils. Environ. Health Perspect. 2010, 118 (7), 10041009.

(11) Lu, K.; Cable, P. H.; Abo, R. P.; Ru, H. Y.; Graffam, M. E.; Schlieper, K. A.; Parry, N. M. A.; Levine, S.; Bodnar, W. M.; Wishnok, J. S.; Styblo, M.; Swenberg, J. A.; Fox, J. G.; Tannenbaum, S. R. Gut Microbiome Perturbations Induced by Bacterial Infection Affect Arsenic Biotransformation. Chem. Res. Toxicol. 2013, 26 (12), 18931903.

(12) Laird, B. D.; Van de Wiele, T. R.; Corriveau, M. C.; Jamieson, H. E.; Parsons, M. B.; Verstraete, W.; Siciliano, S. D. Gastrointestinal microbes increase arsenic bioaccessibility of ingested mine tailings using the simulator of the human intestinal microbial ecosystem. Environ. Sci. Technol. 2007, 41 (15), 5542-5547.

(13) Arumugam, M.; Raes, J.; Pelletier, E.; Le Paslier, D.; Yamada, T.; Mende, D. R.; Fernandes, G. R.; Tap, J.; Bruls, T.; Batto, J. M.; Bertalan, M.; Borruel, N.; Casellas, F.; Fernandez, L.; Gautier, L.; Hansen, T.; Hattori, M.; Hayashi, T.; Kleerebezem, M.; Kurokawa, K.; Leclerc, M.; Levenez, F.; Manichanh, C.; Nielsen, H. B.; Nielsen, T.; Pons, N.; Poulain, J.; Qin, J. J.; Sicheritz-Ponten, T.; Tims, S.; Torrents, D.; Ugarte, E.; Zoetendal, E. G.; Wang, J.; Guarner, F.; Pedersen, O.; de Vos, W. M.; Brunak, S.; Dore, J.; Weissenbach, J.; Ehrlich, S. D.; Bork, P.; Consortium, M. Enterotypes of the human gut microbiome. Nature 2011, 473 (7346), 174-180.

(14) David, L. A.; Maurice, C. F.; Carmody, R. N.; Gootenberg, D. B.; Button, J. E.; Wolfe, B. E.; Ling, A. V.; Devlin, A. S.; Varma, Y.; Fischbach, M. A.; Biddinger, S. B.; Dutton, R. J.; Turnbaugh, P. J. Diet rapidly and reproducibly alters the human gut microbiome. Nature 2013, 505 (7484), 559-563.

(15) Greenblum, S.; Carr, R.; Borenstein, E. Extensive strain-Level copy-number variation across human gut microbiome species. Cell 2015, 160, 583-594.

(16) Van de Wiele, T. R.; Verstraete, W.; Siciliano, S. D. Polycyclic aromatic hydrocarbon release from a soil matrix in the in vitro gastrointestinal tract. J. Environ. Qual. 2004, 33 (4), 1343-1353.

(17) Sun, G. X.; Van de Wiele, T.; Alava, P.; Tack, F.; Du Laing, G. Arsenic in cooked rice: Effect of chemical, enzymatic and microbial processes on bioaccessibility and speciation in the human gastrointestinal tract. Environ. Pollut. 2012, 162, 241-246.
(18) Rowland, I. R; Davies, M. J. In vitro metabolism of inorganic arsenic by the gastro-intestinal microflora of the rat. J. Appl. Toxicol. 1981, 1 (5), 278-283.

(19) Chen, H.; Yoshida, K.; Wanibuchi, H.; Fukushima, S.; Inoue, Y.; Endo, G. Methylation and demethylation of dimethylarsinic acid in rats following chronic oral exposure. Appl. Organomet. Chem. 1996, 10 (9), 741-745.

(20) Yoshida, K.; Inoue, Y.; Kuroda, K.; Chen, H.; Wanibuchi, H.; Fukushima, S.; Endo, G. Urinary excretion of arsenic metabolites after long-term oral administration of various arsenic compounds to rats. J. Toxicol Env Heal A 1998, 54 (3), 179-192.

(21) Naranmandura, H.; Suzuki, N.; Iwata, K.; Hirano, S.; Suzuki, K. T. Arsenic metabolism and thioarsenicals in hamsters and rats. Chem. Res. Toxicol. 2007, 20 (4), 616-624.

(22) Ehlert, K.; Mikutta, C.; Kretzschmar, R. Impact of birnessite on arsenic and iron speciation during microbial reduction of arsenicbearing ferrihydrite. Environ. Sci. Technol. 2014, 48 (19), 1132011329.

(23) Huang, J. H.; Matzner, E. Biogeochemistry of organic and inorganic arsenic species in a forested catchment in Germany. Environ. Sci. Technol. 2007, 41 (5), 1564-1569.

(24) Smeaton, C. M.; Walshe, G. E.; Smith, A. M. L.; HudsonEdwards, K. A.; Dubbin, W. E.; Wright, K.; Beale, A. M.; Fryer, B. J.; Weisener, C. G. Simultaneous release of $\mathrm{Fe}$ and As during the reductive dissolution of $\mathrm{Pb}$-As jarosite by Shewanella putrefaciens CN32. Environ. Sci. Technol. 2012, 46 (23), 12823-12831.

(25) Smith, E.; Scheckel, K.; Miller, B. W.; Weber, J.; Juhasz, A. L. Influence of in vitro assay $\mathrm{pH}$ and extractant composition on As bioaccessibility in contaminated soils. Sci. Total Environ. 2014, 473474, 171-177.

(26) Cui, Y. S.; Chen, X. C. Lead (Pb) and arsenic (As) bioaccessibility in various soils from south China. Environ. Monit. Assess. 2011, 177 (1-4), 481-492.

(27) Kelley, M. E.; Brauning, S. E.; Schoof, R. A.; Ruby, M. V. Assessing Oral Bioavailability of Metals in Soils; Battelle Press: Columbus, OH, 2002.

(28) Bao, S. D. Soil Agrochemical Analysis, 3rd ed.; Agricultural Press: Beijing, China, 2000.

(29) Blott, S. J.; Pye, K. Particle size distribution analysis of sandsized particles by laser diffraction: an experimental investigation of instrument sensitivity and the effects of particle shape. Sedimentology 2006, 53 (3), 671-685.

(30) Klute, A. Methods of Soil Analysis: Part 1: Physical and Mineralogical Methods; SSSA Publications: Madison, WI, 1996.

(31) Kim, E. J.; Yoo, J. C.; Baek, K. Arsenic speciation and bioaccessibility in arsenic-contaminated soils: Sequential extraction and mineralogical investigation. Environ. Pollut. 2014, 186, 29-35.

(32) Van de Wiele, T.; Boon, N.; Possemiers, S.; Jacobs, H.; Verstraete, W. Prebiotic effects of chicory inulin in the simulator of the human intestinal microbial ecosystem. FEMS Microbiol. Ecol. 2004, 51 (1), 143-153.

(33) Tang, X. Y.; Zhu, Y. G.; Cui, Y. S.; Duan, J.; Tang, L. The effect of ageing on the bioaccessibility and fractionation of cadmium in some typical soils of China. Environ. Int. 2006, 32 (5), 682-689.

(34) Rubin, S. S. C. D.; Alava, P.; Zekker, I.; Du Laing, G.; Van de Wiele, T. Arsenic thiolation and the role of sulfate-reducing bacteria from the human intestinal tract. Environ. Health Perspect. 2014, 122 (8), 817-822.

(35) Beak, D. G.; Basta, N. T.; Scheckel, K. G.; Traina, S. J. Bioaccessibility of arsenic $(\mathrm{V})$ bound to ferrihydrite using a simulated gastrointestinal system. Environ. Sci. Technol. 2006, 40 (4), 13641370.

(36) Ravel, B.; Newville, M. ATHENA, ARTEMIS, HEPHAESTUS: data analysis for X-ray absorption spectroscopy using IFEFFIT. J. Synchrotron Radiat. 2005, 12, 537-541.

(37) Beak, D. G.; Wilkin, R. T. Performance of a zerovalent iron reactive barrier for the treatment of arsenic in groundwater: Part 2 . geochemical modeling and solid phase studies. J. Contam. Hydrol. 2009, 106 (1-2), 15-28. 
(38) Ona-Nguema, G.; Morin, G.; Wang, Y. H.; Foster, A. L.; Juillot, F.; Calas, G.; Brown, G. E. XANES evidence for rapid arsenic(III) oxidation at magnetite and ferrihydrite surfaces by dissolved $\mathrm{O}-2$ via $\mathrm{Fe}^{2+}$-mediated reactions. Environ. Sci. Technol. 2010, 44 (14), 54165422.

(39) Herbel, M. J.; Switzer Blum, J.; Hoeft, S. E.; Cohen, S. M.; Arnold, L. L.; Lisak, J.; Stolz, J. F.; Oremland, R. S. Dissimilatory arsenate reductase activity and arsenate-respiring bacteria in bovine rumen fluid, hamster feces, and the termite hindgut. FEMS Microbiol. Ecol. 2002, 41 (1), 59-67.

(40) Yang, J. K.; Barnett, M. O.; Jardine, P. M.; Brooks, S. C. Factors controlling the bioaccessibility of arsenic(V) and lead(II) in soil. Soil Sediment Contam. 2003, 12 (2), 165-179.

(41) Laird, B. D.; Peak, D.; Siciliano, S. D. The effect of residence time and fluid volume to soil mass (LS) ratio on in vitro arsenic bioaccessibility from poorly crystalline scorodite. J. Environ. Sci. Health, Part A: Toxic/Hazard. Subst. Environ. Eng. 2010, 45 (6), 732-739.

(42) Vahter, M. Metabolism of Arsenic; Elsevier Science Press: Oxford, U.K., 1983.

(43) Huang, J. H.; Hu, K. N.; Decker, B. Organic arsenic in the soil environment: speciation, occurrence, transformation, and adsorption behavior. Water, Air, Soil Pollut. 2011, 219 (1-4), 401-415.

(44) Hall, L. L.; George, S. E.; Kohan, M. J.; Styblo, M.; Thomas, D. $\mathrm{J}$. In vitro methylation of inorganic arsenic in mouse intestinal cecum. Toxicol. Appl. Pharmacol. 1997, 147 (1), 101-109.

(45) Jiang, S.; Lee, J. H.; Kim, D.; Kanaly, R. A.; Kim, M. G.; Hur, H. G. Differential Arsenic Mobilization from As-Bearing Ferrihydrite by Iron-Respiring Shewanella Strains with Different Arsenic-Reducing Activities. Environ. Sci. Technol. 2013, 47 (15), 8616-8623.

(46) Whitacre, S. D. Soil controls on arsenic bioaccessibility: Arsenic fractions and soil properties. M.S. Dissertation, The Ohio State University, Columbus, OH, 2010.

(47) Ying, S. C.; Kocar, B. D.; Griffis, S. D.; Fendorf, S. Competitive microbially and $\mathrm{Mn}$ oxide mediated redox processes controlling arsenic speciation and partitioning. Environ. Sci. Technol. 2011, 45 (13), 5572-5579. 